\title{
Conodont micropalaeontology of mid-Ordovician aged limestone clasts from Lower Old Red Sandstone conglomerates, Lanark and Strathmore basins, Midland Valley, Scotland
}

\author{
H. A. ARMSTRONG
}

Department of Geological Sciences, The University, South Road, Durham DH1 3LE, UK

\begin{abstract}
Mid-Ordovician limestone clasts in the Lower Old Red Sandstone conglomerates of the Lanark and Strathmore basins of the Midland Valley, Scotland, were derived from a cryptic carbonate platform, now hidden beneath the Southern Uplands Allochthon. These have yielded 17 multi-element species of conodonts, which are systematically described herein and include the eponymous biozonal species Pygodus serra and Pygodus anserinus. The fauna represents an outer shelf-ocean margin biofacies, found only in Upper Ordovician conglomerates in the Southern Uplands and the Malopolska Terrane, Poland. J. Micropalaeontol. 19(1): 45-59, May 2000
\end{abstract}

\section{INTRODUCTION}

The Midland Valley of Scotland is bounded by the Highland Boundary and Southern Upland faults, both major tectonic boundaries within the northern British Caledonides (Bluck et al., 1992; Fig. 1). Pre-Devonian rocks are only poorly exposed and much of the basement geology has been inferred from studies of clast suites in Ludlow to Devonian age, Lower Old Red Sandstone (LORS) conglomerates. Clasts in conglomerates not only provide indirect evidence of the complex geological history of the Midland Valley (Bluck, 1978, 1983, 1985; Haughton, 1988; Haughton \& Bluck, 1988; Haughton et al., 1990; Bluck et al., 1992) but also the temporal and spatial history of adjacent terranes (Armstrong \& Owen in press).

Smith (1995), Phillips et al., (1997) and Armstrong \& Owen (in press) have revised and reviewed the lithostratigraphy (Fig. 2), macropalaeontology and tectono-stratigraphic setting of the Midland Valley during the Ordovician to Devonian. New finds of conodont-bearing limestone clasts in southerly derived LORS

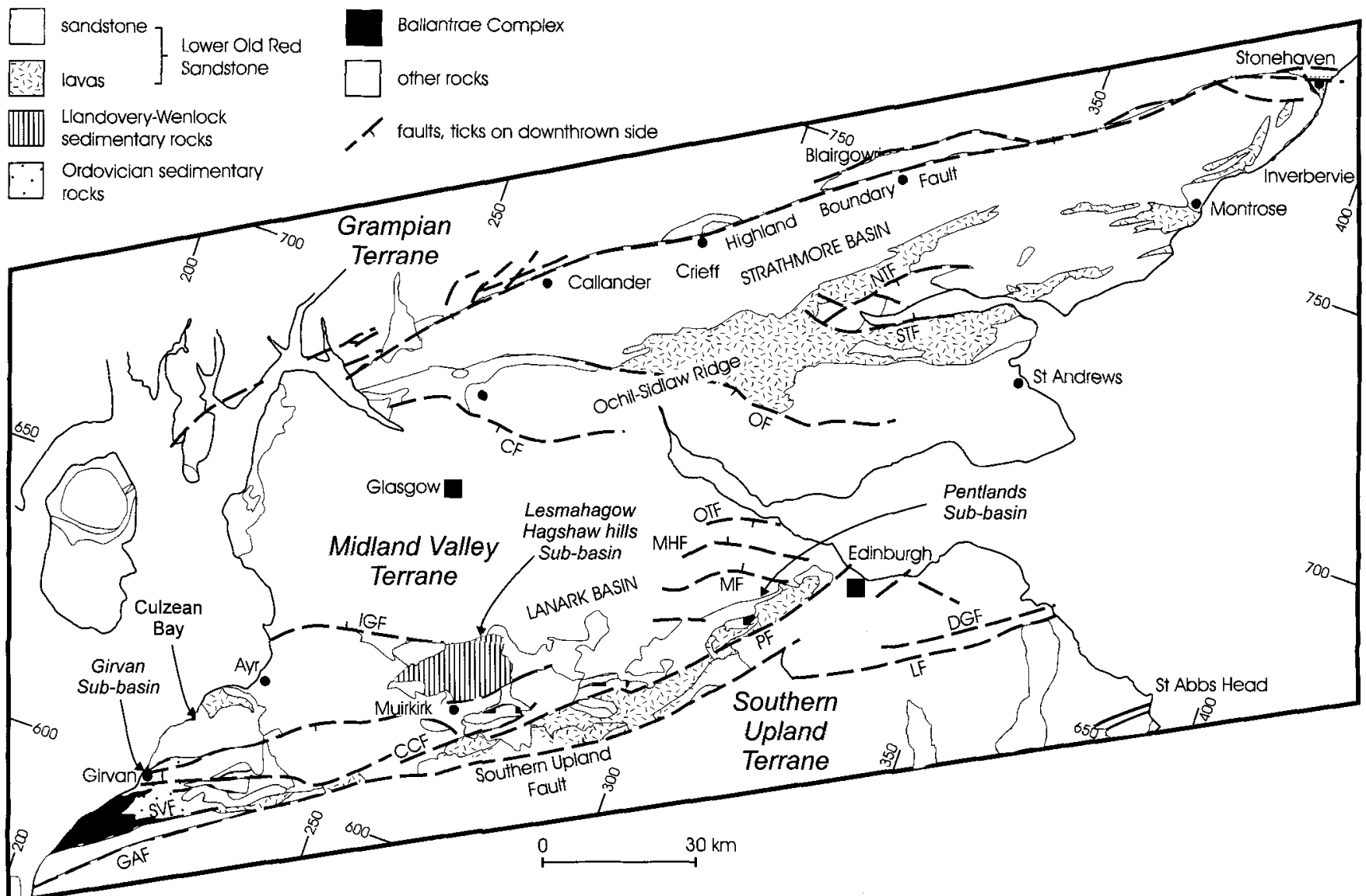

Fig. 1. General geological map of the Midland Valley of Scotland showing the distribution of the Ordovician, Silurian and Lower Old Red Sandstone sedimentary successions. Lower Old Red Sandstone volcanics and the two principal sedimentary basins and sub-basins are marked (redrawn after Phillips et al., 1997). CCF, Carmacoup Fault; CF, Campsie Fault; DGF, Dunbar Gifford fault; GAF, Glen App Fault; IGF, Inchgotrid Fault; KLF, Kerse Loch Fault; LF, Lammemuir Fault; MF, Murieston Fault; MHF, Middleton Fault; NTF, North Tay Fault; OF, Ochil Fault; OTF, Ochiltree Fault; PF, Pentland Fault; STF, South Tay Fault; SVF, Stinchar Valley Fault (redrawn from Armstrong \& Owen in press). 


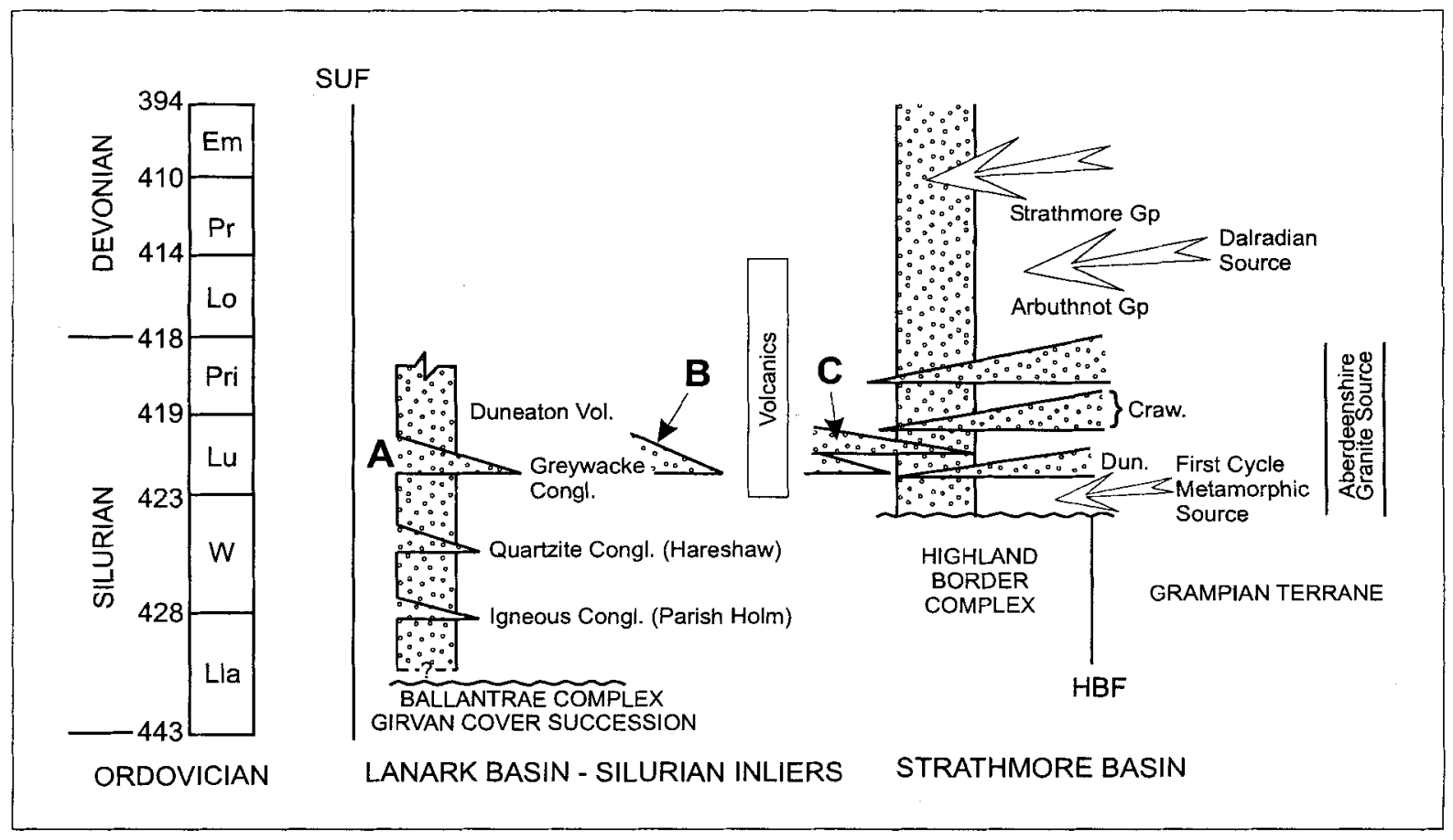

Fig. 2. Chrono- and lithostratigraphy of Ordovician to Devonian successions in the Southern Uplands (composite section), Midland Valley and Grampian terranes, data synthesised from various sources cited in the text. Levels yielding fossiliferous limestone-bearing conglomerates are labelled: A, Greywacke Conglomerate, Culzean Bay; B, Greywacke Conglomerate, Bavelaw Inlier, Pentland Hills; C, Crawton Group, Inverbervie. Lavas above the Greywacke Conglomerate Formation in the Midland Valley are dated at $412.65 .7 \mathrm{Ma}$ (Thirlwall 1988) suggesting that the Greywacke Conglomerate may be late Silurian to earliest Devonian in age, the base of the Devonian system now being dated at about $418 \mathrm{Ma}$ (Tucker et al., 1998). Ordovician and Lower Silurian timescale based on Harland et al., (1990), Upper Silurian and Devonian timescale based on Tucker et al., (1998). SUF, Southern Upland Fault; HBF, Highland Boundary Fault; C, V Chert and volcanics; Craw., Crawton Group; Dun., Dunnottar Group; K, Kirkcolm Formation; Kirk Kirkland Conglomerate; M, Marchburn Formation; P, Portpatrick Formation; Sh, Shinnel Formation; Tw, Tweeddale Member.

conglomerates in the Lanark and Strathmore Basins and the Pentland Hills Inlier, Midland Valley, Scotland (Fig. 2), were reported by Armstrong et al. (2000) and Armstrong \& Owen (in press).

Conodonts indicate that the source for the limestone clasts was a cryptic carbonate platform of mid-Ordovician, Pygodus serra $-P$. anserinus Biozone age, now hidden beneath the allochthonous Southern Uplands (Armstrong \& Owen in press). The fauna from the limestone clasts is more closely similar to coeval faunas in Upper Ordovician limestone-bearing conglomerates from Ordovician conglomerates in the Southern Uplands and the Mójcza Limestone, Malopolska Terrane, Poland, than to those from the Laurentian margin including Girvan (Armstrong \& Owen in press). To reconcile this distribution, Armstrong \& Owen (in press) conclude that it is most likely that the taxa present in the clasts represent an outer shelf - ocean margin biofacies. The aim of this paper is to describe 'systematically' conodonts from the southerly derived limestone-bearing conglomerates within the Midland Valley succession.

\section{CONODONT BIOSTRATIGRAPHY}

The presence of the eponymous biozonal species Pygodus serra and Pygodus anserinus in the clast faunas indicate a late Llanvirn-early Caradoc, Llandeilian to Aurelucian age (sensu Fortey et al., 1995) for the limestone clasts in the LORS of the
Midland Valley (Armstrong \& Owen in press). Bergström (1990) documented the stratigraphical distribution of conodont species in the Barr Group at Girvan. Pygodus serra first appears in the lower Stinchar Limestone (Bergström, 1990, fig. 3) and the $P$. serra-P. anserinus Biozone boundary lies at a level in the middle of the Stinchar Limestone. Bergström $(1973,1986)$ placed the base of the $P$. serra Biozone within the mid- D. murchisoni graptolite biozone (Abereiddian) and the top of the $P$. anserinus Biozone at a level within the mid- $N$. gracilis graptolite biozone (Aurelucian). Consequently the $P$. serra Biozone lies within the Llanvirn and much of the $P$. anserinus Biozone lies within the Caradoc (sensu Fortey et al., 1995). Armstrong et al., (1996) reviewed the biostratigraphy of mid-Ordovician conodont faunas in southern Scotland, indicating that correlations could be made across the Southern Upland Fault.

\section{METHODS}

Samples of limestone up to $2 \mathrm{~kg}$ were processed using standard preparation techniques of acid dissolution in buffered $10 \%$ acetic acid and bromoform separation. Clasts were processed separately and processed weights and specimen abundances are recorded in Table 1. Conodonts are most abundant in the sparry limestone clasts from Culzean Bay. In general the preservation is moderate to poor with conodont colour alteration index (CAI) values ranging from 5 to 6 indicating heating to in excess of 
Table 1. Sample localities and specimen abundances.

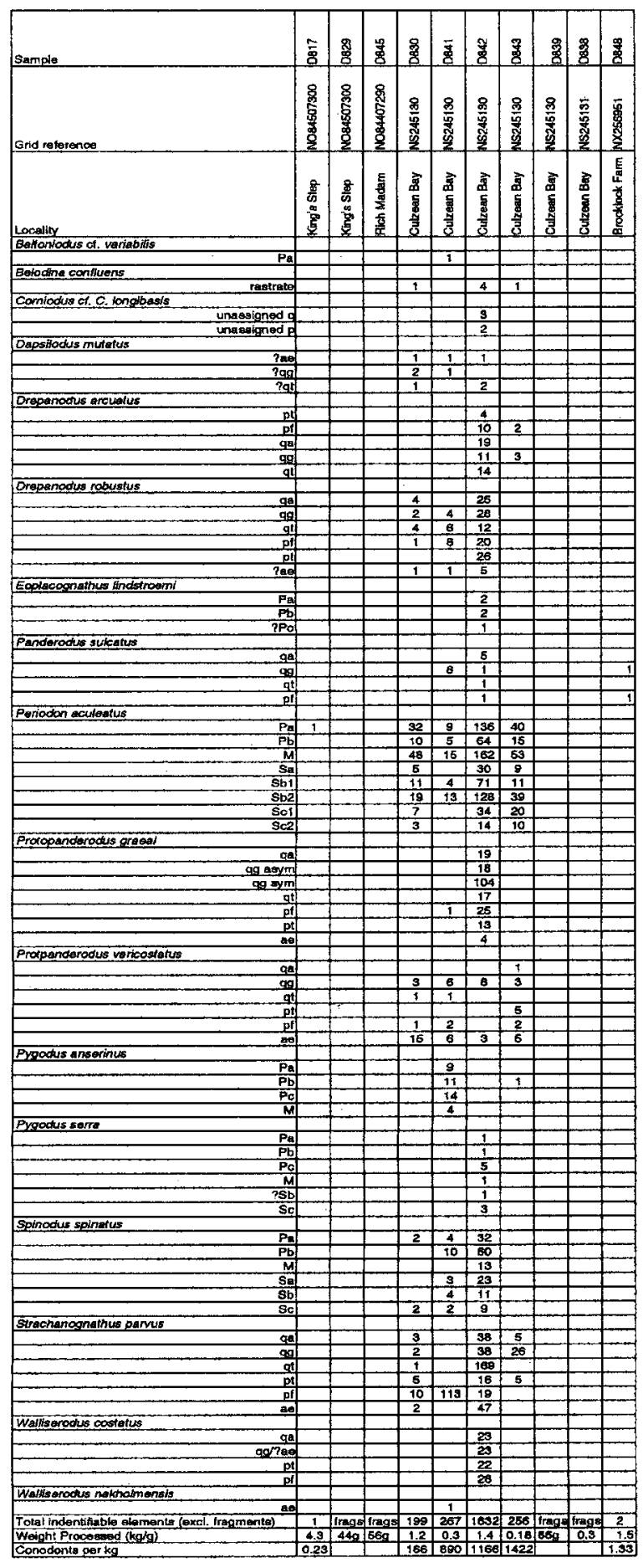

$300^{\circ} \mathrm{C}$ (Rejebian et al., 1987). The majority of specimens show mineral overgrowth and surface recrystallization.

\section{SYSTEMATIC PALAEONTOLOGY}

The species recorded from the limestone clasts are generally well known and full descriptions of elements can be found in cited publications, particularly Dzik (1994) and Armstrong (1997). Abbreviated synonomies include the holotype (*), first multielement reconstruction and the most recent reference to embrace the concept favoured herein. Figured specimens (prefix GLAHM) are housed in the Hunterian Museum, Glasgow. The remainder of the collection is stored in the micropalaeontological collections at the University of Durham.

The notational scheme proposed by Sweet \& Schönlaub (1975) and modified by Cooper (1975) for ramiform taxa is adopted here as it remains the most widely used amongst conodont workers. The major shape categories and morphological terminology for ramiform taxa are as employed by Sweet (1981). The major shape categories and morphological terminology are used to describe coniform elements follow Sweet (1988) as modified by Sansom et al., (1994).

The application of element location schemes to coniform taxa depends largely upon inference, rather than homology, as few bedding plane assemblages exist. Purists would argue that until such assemblages are found it would be prudent to delay the use of element location terminology. Sansom et al., (1994) developed an element location scheme and functional paradigm for panderodontid conodonts based upon a bedding plane assemblage and diagenetic clusters of Panderodus unicostatus that appears to be more widely applicable to other coniform taxa. Of particular use is the recognition that coniform apparatuses comprised three morphologically and functionally distinct domains. In the panderodontids the perfectly symmetrical ae element must have lain on the mid-line of the animal and of all the elements could be homologous to the Sa element of ramiform bearing apparatuses. The anterior domain of multiple pairs of grasping $q$ elements is homologous to the $S$ elements in ramiform bearing apparatuses. The posterior domain of two pairs of food processing, $p$ elements is probably homologous to the $\mathbf{P}$ elements in ramiform-bearing apparatuses. $\mathrm{A}$ functional homologue of the $\mathbf{M}$ element in ramiform taxa is not obvious and if the ae element may have fulfilled the role of an opposing grasping element it would, therefore, not be homologous to the Sa element.

In the absence of direct evidence from bedding plane assemblages it is difficult to homologize element locations between the panderodontids and other coniform taxa. The inferred locational nomenclature applied to non-panderodontid coniform taxa herein should therefore be regarded as preliminary. The application of $\mathrm{P}, \mathrm{M}$ and particularly $\mathrm{S}$ element terminology to coniform apparatuses is considered highly speculative.

The fauna contains the following taxa for which little new taxonomic information is provided:

Belodina confluens Sweet, 1979, Pl. 5, fig. 3. Panderodus sulcatus (Fåhræus, 1966), Pl. 4, figs 16-20; Pl. 5, figs $1,2$.

Cornuodus cf. C. longibasis (Lindström, 1955), Pl. 1, figs 1, 2. Dapsilodus mutatus (Branson \& Mehl, 1933), Pl. 1, figs 3-6; P1. 2, figs 14-15.

Walliserodus nakholmensis (Hamar, 1966), Pl. 1, fig. 15. Strachanognathus parvus Rhodes, 1955 sensu Armstrong, 1997, Pl. 5, figs 6-16. 


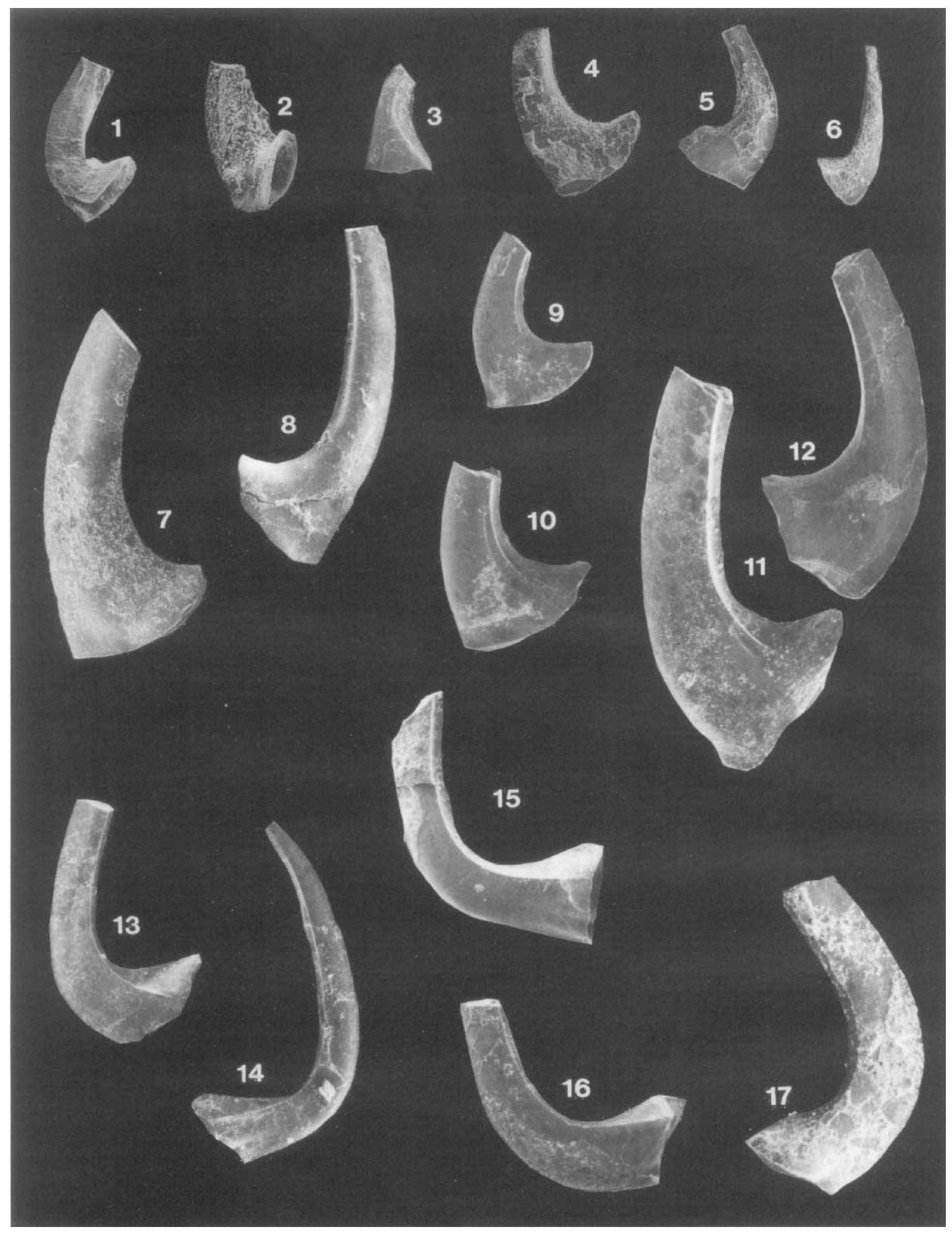

Explanation of Plate 1

figs 1, 2 Cornuodus cf. C. longibasis. Specimens from sample D842. fig. 1, specimen GLAHM 109139, $\times 70$; fig. 2, specimen GLAHM 109140, $\times 70$. figs 3-6 Dapsilodus mutatus (Branson \& Mehl, 1933). Specimens from sample D830. fig. 3, symmetrical costate element (?ae) outer view, specimen GLAHM 109141, ×70; fig. 4, outer view of falciform acostate (?qg) element, specimen GLAHM 109142, $\times 50$; fig. 5, inner outer view of falciform acostate (?qg) element, specimen GLAHM 109143, $\times 50$; fig.6, outer view of acostate truncatiform element (?qt), specimen GLAHM 109144, $\times 70$. figs 7-12 Drepanodus robustus Hadding, 1913. Specimens from sample D842. fig. 7, inner view of qg element, specimen GLAHM 109145, $\times 50 ;$ fig. 8, inner view of qg element, specimen GLAHM 109146, $\times$ 40; fig. 9, outer view of qt element, specimen GLAHM 109147, $\times 80$; fig. 10, inner view of qt element, specimen GLAHM 109148, $\times 80$; fig. 11, inner view of qa element, specimen GLAHM 109149, $\times 80$; fig. 12, outer view of qa element, specimen GLAHM 109150, $\times 80$. figs 13-17 Protopanderodus graeai (Hamar, 1966). Specimens from sample D842. fig. 13, inner view of symmetrical qg element, specimen GLAHM 109151, ×80; fig. 14, outer view of symmetrical qg element, specimen GLAHM 109152, $\times 80$; fig. 15, ae element, specimen GLAHM 109153, ×40; fig. 16, symmetrical ?qg/qt element, specimen GLAHM 109154, ×80; fig. 17, symmetrical ?qg/qt element, specimen GLAHM 109155, ×80. 
Baltoniodus cf. variabilis (Bergström, 1962). A single broken specimen of a pastinate Pa element was found in sample D841, this was unsuitable for illustration.

\section{Phylum Chordata \\ Class Conodonta \\ Order Protopanderodintida Sweet, 1988.}

Remarks. The Protopanderodontida includes conodonts from a number of families (Aldridge \& Smith, 1993) bearing apparatuses comprising longitudinally costate and striated, coniform elements. Members of the Protopanderodontida appear to have a panderodontid apparatus plan but lack the furrow typical of panderodontids. A homologous structure appears to be formed from the longitudinal costae (Armstrong, 1997).

\section{Family Protopanderodontidae (Lindström, 1970) Genus Drepanodus Pander, 1856}

Type species. Drepanodus arcuatus Pander, 1856.

Remarks. Lindström (in Ziegler, 1973, p. 65) recognized 'drepanodontiform' and 'oistodontiform' elements in his emended diagnosis of Drepanodus. These equate with the $\mathrm{q}$ and $\mathrm{p}$ elements respectively and subsequent additions to the apparatus can be considered as subcategories of these main types (van Wamel, 1974; Löfgren, 1978; Dzik, 1990, 1994). Drepanodus arcutatus has a panderodontid apparatus comprising an anterior domain of laterally compressed, commonly smooth, q elements and a posterior domain with a falciform pf and tortiform pt. Both $\mathrm{p}$ elements have laterally flared bases, the inner margin of which bear a prominent basal notch. The ae element more closely resembles the morphology of the $p$ elements. Contrary to Dzik (1994, p. 68) species are best distinguished on the basis of $\mathrm{p}$ element morphology,

Drepanodus shares a similar apparatus plan with Protopanderodus and there is a marked convergence (or parallelism) in the morphology of the q elements in these taxa. The fused cluster of elements figured by McCracken (1989, pl. 2, figs 1-5), as Protopanderodus sp. A, contains a falciform pf element with a prominent basal notch and thus falls into the concept of Drepanodus advocated herein. There seems to be little substantive evidence to support a continued separation of the two genera at family level.

\section{Drepanodus arcuatus Pander, 1856}

$$
\text { (P1. 3, figs 1-18) }
$$

* 1856 Drepanodus arcuatus Pander: 20, pl. 1 figs 2, 4, 5, 17, ?pl. 1 , figs $6-8$.

1974 Drepanodus arcuatus Pander; van Wamel: 61, pl. 1 Figs 10-13. 1978 Drepanodus arcuatus Pander; Löfgren: 51, pl. 2 figs 1-8. 1994 Drepanodus arcuatus Pander; Dzik, 6: pl. 15 figs 2-6.

Holotype. Drepanodus arcuatus Pander, 1856, p. 20 Emended diagnosis. A species of Drepanodus in which the falciform pf and tortiform pt elements bear a single, upwardly pointing, carina or costa on either side of the upper edge keel.

Remarks. The pf and pt elements of this species are of similar morphology and costate; the $q$ elements are essentially acostate, only the qa element bears an indistinct inwardly directed lower edge keel. The falciform pf has prominent upper and lower edge keels and a single, upwardly pointing, costa flanks the upper keel. The pt has a broader basal flare and the cusp is twisted towards the outer face, away from the basal notch. The costae on the p elements become less prominent in younger examples of this species. Dzik (1994, pl. 15, fig. 5) illustrated the pt element and homologized this with the $\mathrm{Pb}$ ('oz' sensu Dzik) element of the ozarkodinid apparatus; this implies a location in the apparatus just to the posterior of the $\mathrm{q}$ elements. The fused cluster illustrated by McCracken (1989, pl. 2, fig. 1) has a falciform $\mathrm{pf}$ and not a tortiform pt element fused to the $\mathrm{q}$ elements. In Panderodus unicostatus the falciform pf element is located posterior of the q elements (Sansom et al., 1994) with the pt element the most posterior element in the apparatus. If these elements can be considered homologous with those in ozarkodinid conodonts then the pt and the pf elements would be homologous with the $\mathrm{Pa}$ and $\mathrm{Pb}$ elements respectively. The aequaliform ae element of $D$. arcuatus resembles the pf element but is smaller and is more markedly recurved.

$$
\begin{gathered}
\text { Drepanodus robustus Hadding, } 1913 \\
\text { (Pl. 1, figs 7-12; Pl. 2, figs 12, 13) }
\end{gathered}
$$

* 1913 Drepanodus robustus Hadding: 31, pl. 1, fig. 5

1971 Drepanodus robustus Hadding; Lindström: 41.

1978 Protopanderodus robustus Hadding; Löfgren: 94, pl. 3, figs 32-35, fig. 31G-J.

1994 Drepanodus robustus Hadding; Dzik: 70, pl. 14, figs 10-14

Holotype. Drepanodus robustus Hadding, 1913, p. 31, from the lower Dicellograptus Shale, base of section E14a of Fågelsång near Lund, Skåne, Sweden.

Diagnosis. Refer to Dzik (1994, p. 70).

Remarks. Löfgren (1978) considered the holotype of $D$. robustus to be a member of Protopanderodus. Drepanodus robustus has $\mathrm{p}$ elements that have up to four prominent costae on their lateral faces.

\section{Genus Protopanderodus Lindström, 1971}

Type species. Acontiodus rectus Lindström, 1955.

Remarks. Armstrong (1997) noted the panderodontid nature of the Protopanderodus apparatus. Both $\mathrm{p}$ and $\mathrm{q}$ elements are costate and species can be distinguished on the number of lateral face costae on the pf element and by the ae element which varies with respect to the degree of upward flaring of the basal cavity.

$$
\begin{gathered}
\text { Protopanderodus graeai (Hamar, 1966) } \\
\text { (P1. 1, figs 13-17; P1. 2, figs 6-11, 16) }
\end{gathered}
$$

* 1966 Acodus graeai Hamar: 47, pl. 3, figs 11-14, text-fig. 3:5 1978 Protopanderodus graeai (Hamar); Löfgren: 93, pl. 3, figs 19-25 text-fig. 3I, K-M.

1994 Protopanderodus graeai (Hamar); Dzik: 72, pl. 13, figs 14 22 , text-fig. $10 \mathrm{~b}-\mathrm{c}$.

Holotype. Acodus graeai Hamar, 1966, p. 47, from sample 187 within the upper $10 \mathrm{~m}$ of the Ampyx Limestone at Rødeløkken, Bygdøy Penninsula, Oslo, Norway.

Diagnosis. Refer to Dzik (1994, 72).

Remarks. $P$. graeai elements have flatter bases than other species; pf element is markedly recurved, has a lower edge keel and upper edge costa. Specimens tentatively designated pt elements have two costae merging to form the upper edge of the 


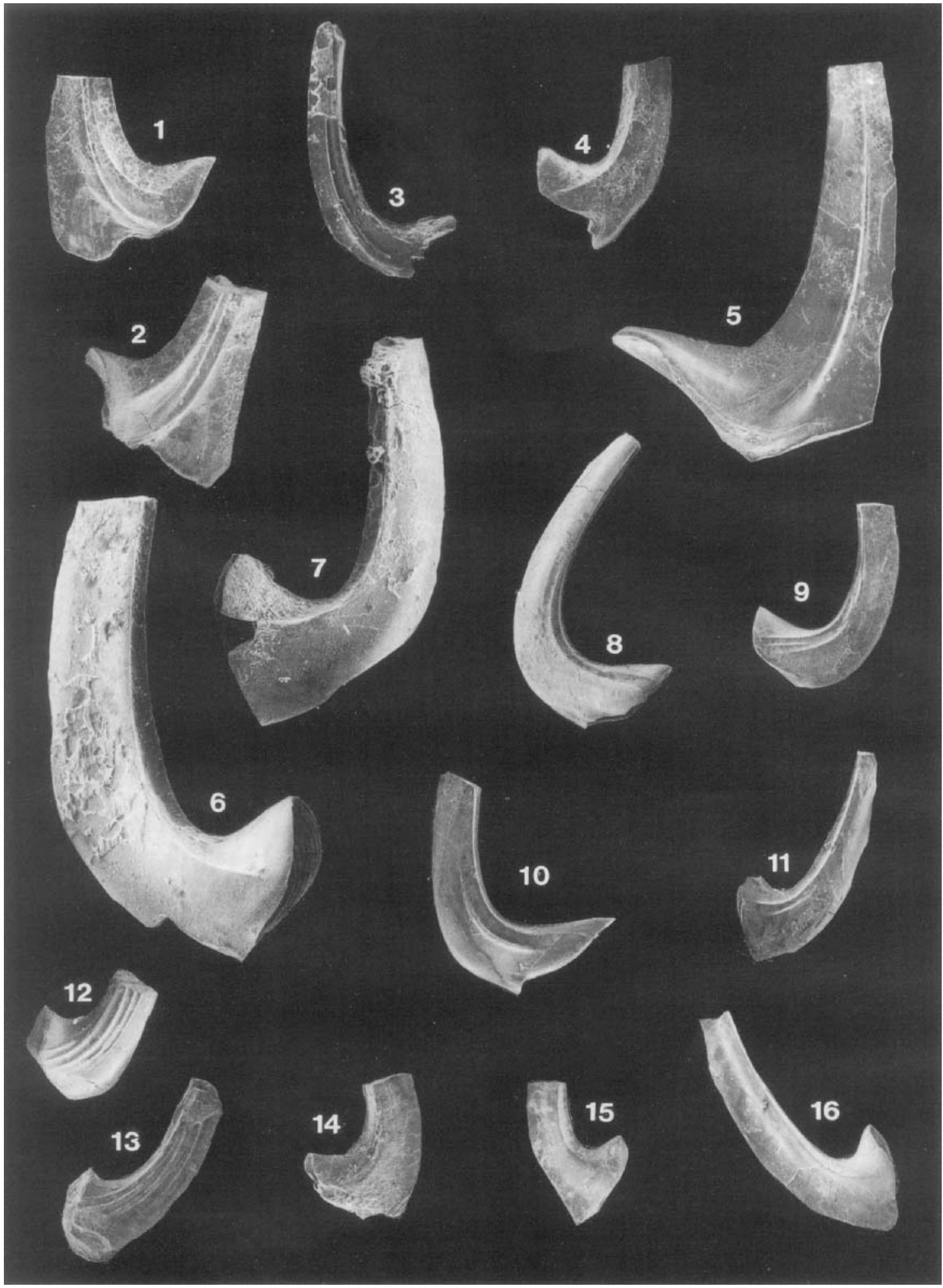

Explanation of Plate 2

figs 1-5 Protopanderodus varicostatus (Sweet \& Bergström, 1962). fig. 1, pf element specimen GLAHM 109156, sample D843, $\times 50$; fig. 2, pf element, specimen GLAHM 109157, sample D843, $\times 50$; fig. 3, costate qg element, specimen GLAHM 109158, sample D842, $\times 50$; fig. 4, ae element, specimen GLAHM 109159, ×50; fig. 5, inner view pt element, specimen GLAHM 109160, sample D843, ×50. figs 6-11, 16 Protoparderodus graeai (Hamar, 1966). Specimens from D842. fig. 6, qa element, specimen GLAHM 109161, $\times 50$; fig. 7, qa element, specimen GLAHM 109162, $\times 50$; fig. 8, asymmetrical qg element inner, specimen GLAHM 109163, $\times 40$; fig. 9, asymmetrical ?p element outer, specimen GLAHM 109164, $\times 40$; fig. 10, asymmetrical ?p element inner, specimen GLAHM 109165, $\times 40$; fig. 11, ?pf element outer, specimen GLAHM 109166, $\times 40$; fig. 16, pf element inner, specimen GLAHM 109171, $\times 40$. figs 12, 13 Drepanodus robustus Hadding, 1913. Specimens from sample D842. fig. 12, pf element outer, specimen GLAHM 109167, ×40; fig. 13, pf element inner, specimen GLAHM 109168, ×40; figs 14, 15 Dapsilodus mutatus (Branson \& Mehl, 1933). Specimens from D842. fig. 14, q element outer, specimen GLAHM 109169, ×40; fig. 15, ae element, specimen GLAHM $109170, \times 40$. 


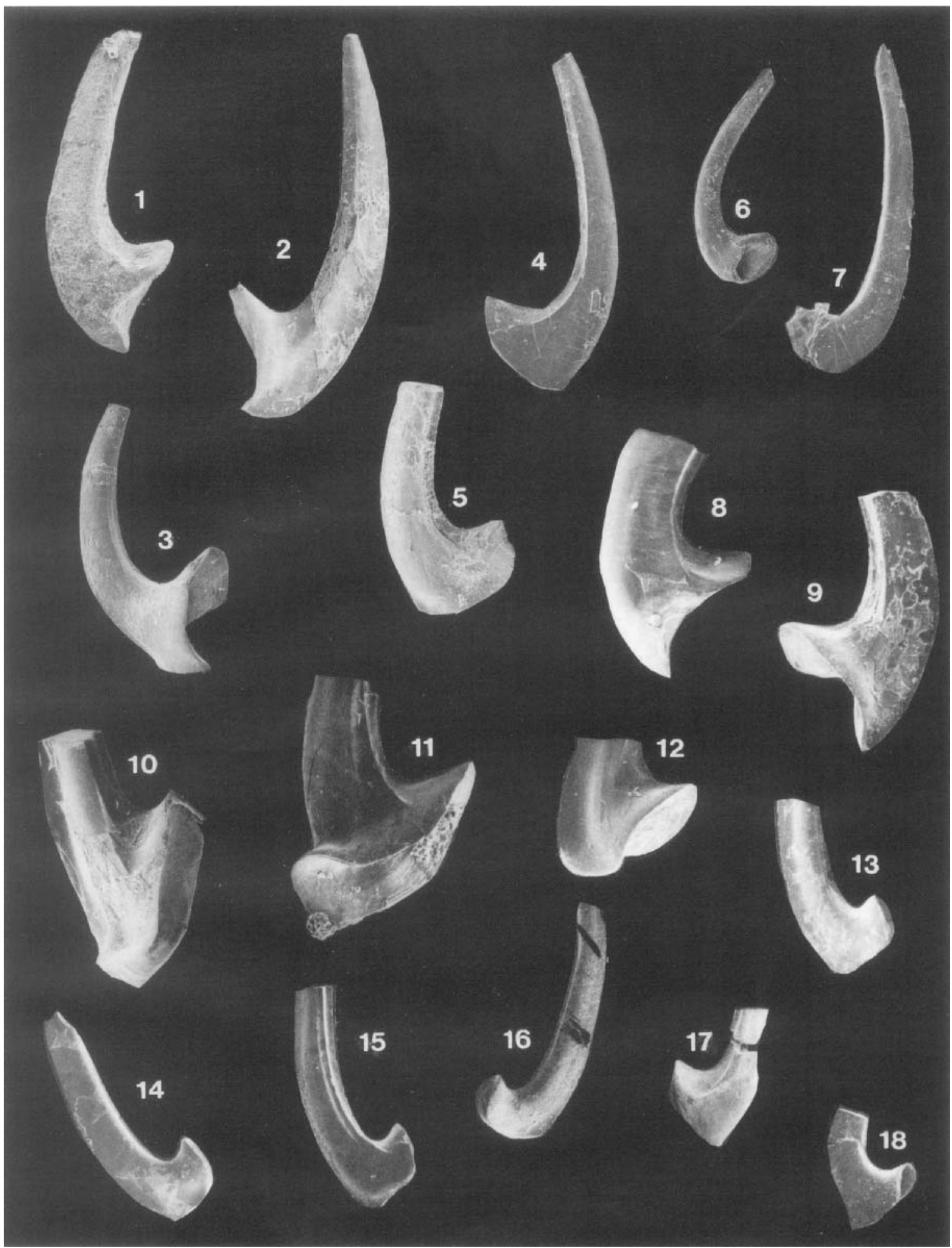

Explanation of Plate 3

figs 1-18 Drepanodus arcuatus Pander, 1856. Specimens from sample D842. fig. 1, pf element outer, specimen GLAHM 109172, $\times 50$; fig. 2, pf element inner, specimen GLAHM 109173, D842, ×50; fig. 3, pt element, specimen GLAHM 109174, $\times 50$; fig. 4, large qt element outer, specimen GLAHM 109175 , $\times 50$; fig. 5, gg element inner, specimen GLAHM 109176, ×50; fig. 6, ?gg element, specimen GLAHM 109177, ×50; fig. 7, ?qg elenent, specimen GLAHM 109178, ×50; fig. 8, pf element outer, specimen GLAHM 109179, ×50; fig. 9, pf element inner, specimen GLAHM 109180, $\times 50$; fig. 10, pt element oblique inner, specimen GLAHM 109181, $\times 50$; fig. 11, pt element outer, specimen GLAHM 109182, $\times 50$; fig. 12, ?ae element specimen GLAHM 109183, ×50; fig.13, qa element inner, specimen GLAHM 109184, ×40; fig. 14, qg element outer, specimen GLAHM 109185, $\times 40$; fig. 15, qq element outer, specimen GLAHM 109186, ×40; fig. 16, qa element inner, specimen GLAHM 109187, $\times 40$; fig. 17, qt element outer, specimen GLAHM 109188, ×40; fig. 18, qt element inner, specimen GLAHM 109189, ×40. 
lateral faces and the base is more upwardly flared than in other elements. q elements have smooth faces and a costa close to the upper edge. qg elements dominate this collection with low (PI. 1, fig. 13) and high-based (Pl. 1, fig. 14; Pl. 2, fig. 8) forms present. The qa element is larger than the other elements and bears a weakly developed inwardly directed keel; the outer face has a single costa close to the upper edge. An unequivocal qt element cannot be distinguished in this collection. The ae element is similar to the high-based qg but has a flat base.

Protopanderodus varicostatus (Sweet \& Bergström, 1962) (Pl. 2, figs 1-5; Pl. 4, figs 1-5)

* 1962 Scolopodus varicostatus Sweet \& Bergström: 1247, pl. 168, figs 4-9; text-fig. 1A, C, K.

1974 Protopanderodus varicostatus (Sweet \& Bergström); Bergström et al.: pl. 1, figs 9-10.

1994 Protopanderodus varicostatus (Sweet \& Bergström); Dzik: 74 , pl. 14 , figs $1-5$, text-fig. $11 \mathrm{~b}$.

Holotype. Scolopodus varicostatus Sweet \& Bergström, 1962, p. 1247: from the Pratt Ferry Formation (Middle Ordovician), Alabama.

Diagnosis. Refer to Armstrong (1997).

Remarks. Atypically, elements from this collection are small and slender and may represent juveniles. In this species the pf and qg elements each bear a pair well developed longitudinal costae on the inner and outer faces. The pt element only has a single costa on the inner face. The upward flare of the basal cavity of the ae element is not as well developed as in larger specimens.

\section{Genus Walliserodus Serpagli, 1967}

Type species. Acodus curvatus Branson \& Branson, 1947, by subsequent designation of Cooper (1975, p. 995).

Remarks. Armstrong (1990) reconstructed the apparatus of Silurian Walliserodus, demonstrating that it possessed a fully developed panderodontid apparatus plan. At that time it was not clear whether Ordovician and Silurian Walliserodus were congeneric. $W$. costatus in this collection appears to lack a $\mathrm{qt}$ element and the $\mathrm{qg} /$ ?ae element (Pl. 4, figs 12, 13) is difficult to homologize. In $W$. curvatus the latter and closely comparable element is symmetrical and was considered by Armstrong (1990) to be an ae element. In $W$. costatus this element is inwardly bowed (P1. 4, fig. 13), suggesting it could not have occupied a location on the mid-line of the animal and is more likely to have occupied the qg location. These observations indicate either there have been considerable changes in the apparatus of Walliserodus through evolution or that Ordovician and Silurian Walliserodus are not congeneric.
Walliserodus costatus Dzik, 1976

(Pl. 4, figs 6-14)

* 1976 Walliserodus costatus Dzik: 421, pl. 41, fig. 2, text-fig. $14 \mathrm{~m}, \mathrm{n}$.

1994 Walliserodus costatus Dzik: Dzik: 56, pl. 12, figs 1-6, textfig. $2 \mathrm{a}$.

1997 Walliserodus aff. W. sancticlairi Cooper; Armstrong: 784, pl. 5, figs 6-9.

Holotype. Walliserodus costatus Dzik, specimen ZPAL CV1/307 from sample MA-14 Mojcza Limestone, Holy Cross Mountains, Poland.

Diagnosis. Refer to Dzik (1994, p. 56).

Remarks. The ?qg/?ae element of $W$. costatus closely resembles that of the Silurian species $W$. curvatus, but differs in being inwardly bowed. The ?qg/?ae element of $W$. nakholmensis is laterally compressed and bears multiple costae on the lateral faces; the lower edge costa is also less prominent.

Order Prioniodinida Sweet, 1981

Family Periodontidae Lindström, 1970

Genus Periodon Hadding, 1913

Periodon aculeatus (Hadding, 1913)

(Pl. 6, figs 14-18; Pl. 7, figs 1-6)

* 1913 Periodon aculeatus Hadding: p. 33, pl. 1, fig. 14.

1966 Periodon aculeatus (Hadding); Sweet \& Bergström: pl. 18, figs $1,3-4$, text-figs $1 \mathrm{C}, \mathrm{E}$.

1974 Periodon aculeatus (Hadding); Bergström et al.: pl. 1, figs 4-6.

1976 Periodon aculeatus (Hadding); Dzik: figs 34i-r.

1997 Periodon aculeatus (Hadding); Armstrong: 774, pl. 2, figs 13-21; text-fig. 3

Holotype. Hadding (1913, pl. 1, fig. 14) specimen LO $2353 \mathrm{~T}$ (mouldic preservation); Climacograptus haddingi Biozone $(=\mathrm{Cli}$ macograptus putillus in Hadding, 1913), from the upper part of section E15 of Fågelsång near Lund, Skåne, Sweden

Diagnosis. Refer to Armstrong (1997, p. 774).

Remarks. The supra-generic classification of Periodon is somewhat confused. Aldridge \& Smith (1993) followed Sweet (1981) and classified Periodon in the Family Periodontidae, Order Prioniodontida. Dzik (1994) moved the Periodontidae to the Order Ozarkodinida. Armstrong (1997) placed Periodon in the Prioniodontida but transferred the genus to the Prioniodontidae.

Periodon aculeatus has an extensiform digyrate (or angulate) $\mathrm{Pa}$, a breviform digyrate $\mathrm{Pb}$ and a dolabrate $\mathrm{M}$ element,

\section{Explanation of Plate 4}

figs 1-5. Protopanderodus cf. $P$, varicostatus. Specimens from D842. fig. 1, pf element, specimen GLAHM 109190, $\times 40$; fig. 2, pf element, specimen GLAHM 109191, $\times 50$; fig. 3, pt element, specimen GLAHM 109192, ×40; fig. 4,Protopanderodus varicostatus (Swcet \& Bergström, 1962), qg element, specimen GLAHM 109193, ×50; fig. 5,?qt element specimen GLAHM 109194, $\times 50$. figs 6-14. Walliserodus costatus (Dzik, 1976). Specimens from D842. fig. 6, pt element inner, specimen GLAHM 109195, x50; fig. 7, pt element inner, specimen GLAHM 109196, $\times 50$; fig. 8, pt element outer, specimen GLAHM 109197, ×50; fig. 9, pf element, specimen GLAHM 109198, ×50; fig. 10, qa element outer, specimen GLAHM 109199, $\times 50$; fig. 11, qa element inner, specimen GLAHM 109200, $\times 50$; fig. 12, qg/?ae element, specimen GLAHM 109201, $\times 50$; fig. 13, qg/?ae element, specimen GLAHM 109202, $\times 50$; fig. 14, Walliserodus costatus (Dzik, 1976), qa element inner, specimen GLAHM 109203, $\times 50$. fig. 15 Walliserodus nakholmensis (Hamar, 1966), ae element, specimen GLAHM 109204, sample D841, $\times 70$. figs 16-20 Panderodus sulcatus (Fåhræus, 1966). Specimens from D842. fig. 16, pf element, specimen GLAHM 109205, $\times 70$; fig. 17, qa element outer, specimen GLAHM 109206, $\times 70$; fig. 18, qa element inner, specimen GLAHM 109207, ×70; fig. 19, qt element outer, specimen GLAHM 109208, ×70; fig. 20, qg element inner, specimen GLAHM 109209, $\times 70$. 


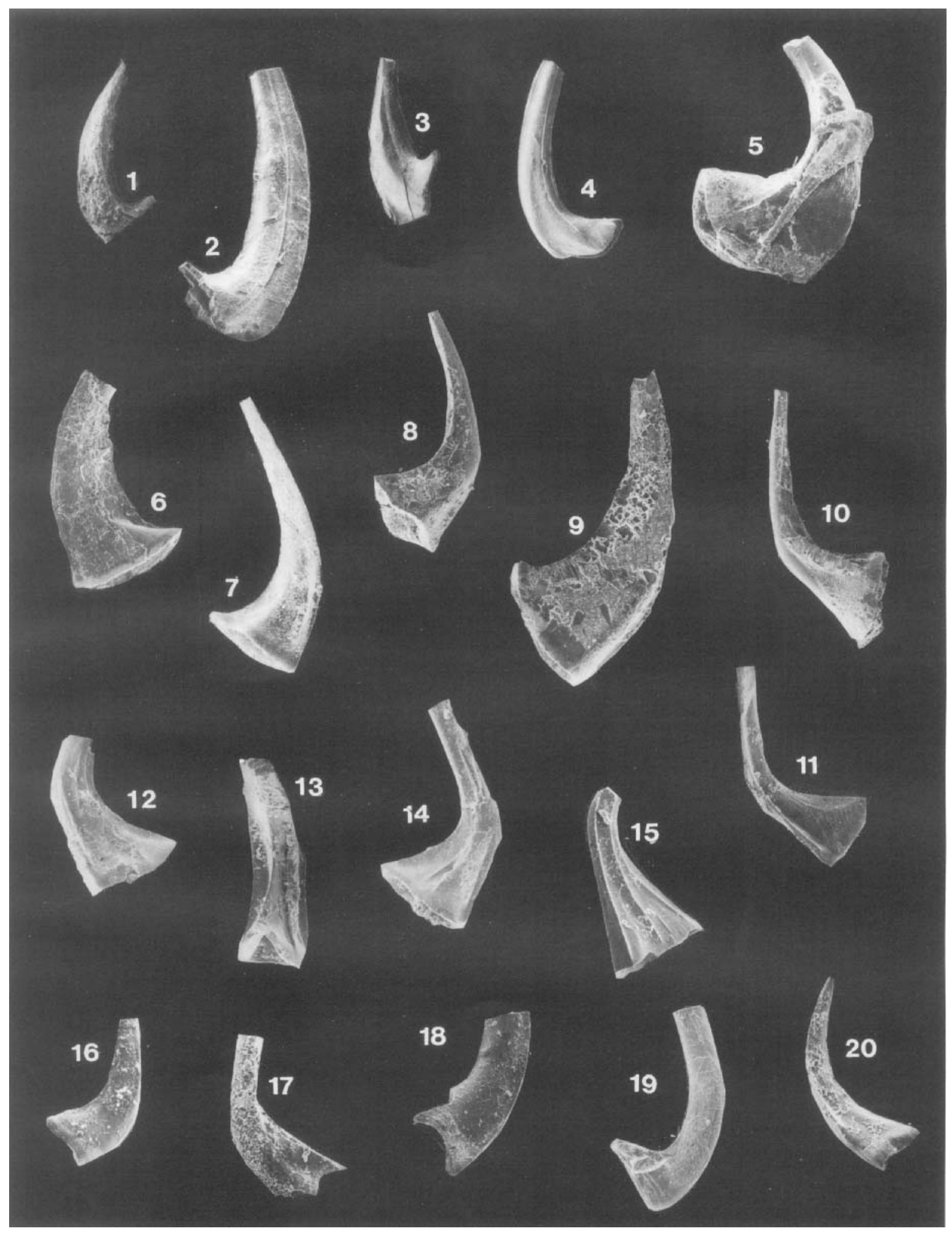




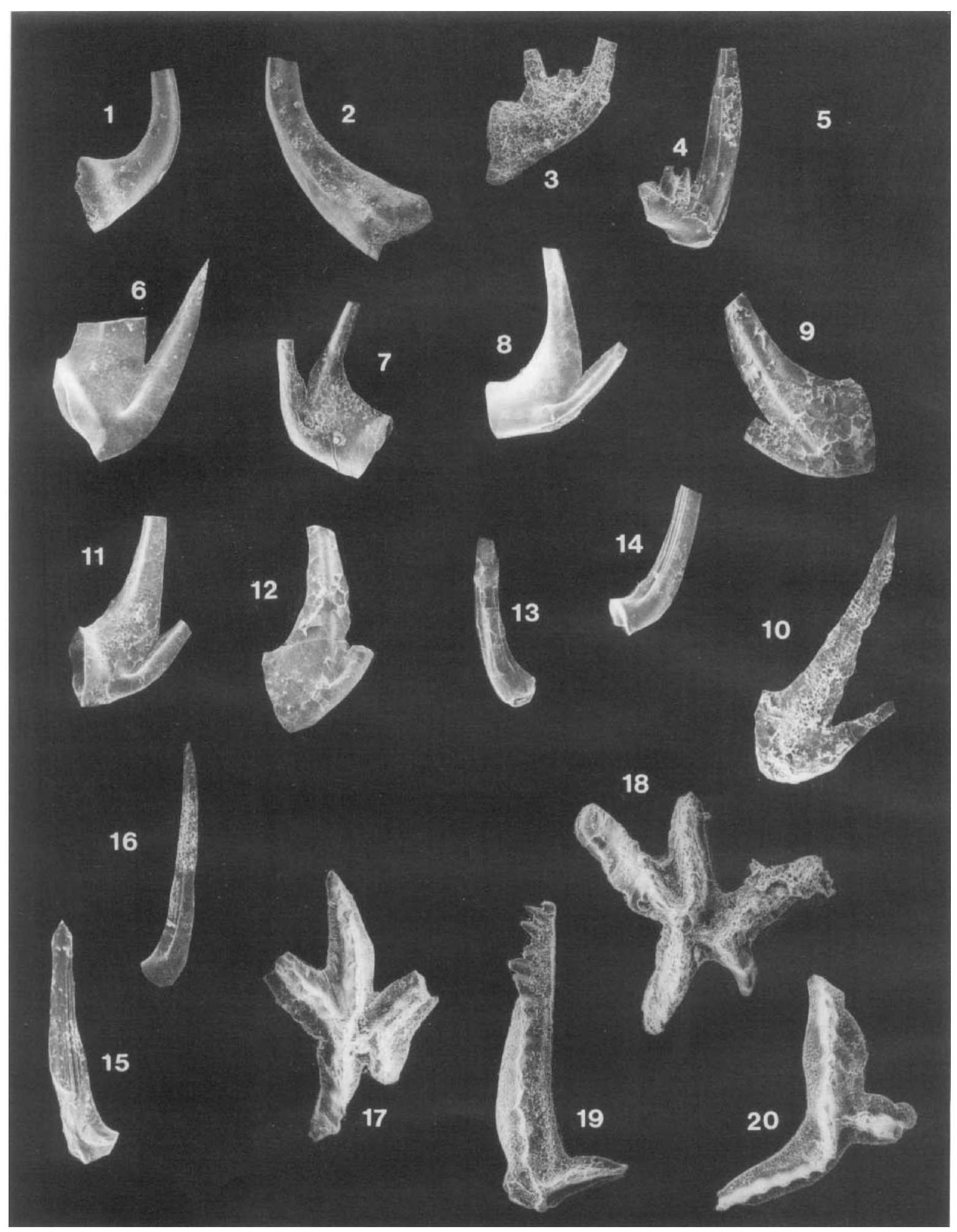

Explanation of Plate 5

figs 1, 2 Panderodus sulcatus (Fåhræus, 1966). Fig.1, pf element, specimen GLAHM 109210, sample D848, $\times 70 ;$ fig. 2, qg element, specimen GLAHM 109211, sample D848, $\times 70$. fig. 3 Belodina confluens Sweet 1979, rastrate element, specimen GLAHM 109212, sample D842, $\times 70$. figs 4-5 Pygodus serra (Hadding, 1913). fig. 4, Sc element, specimen GLAHM 109213, sample D842, x70; fig. 5, Sc element, specimen GLAHM 109214, sample D842, $\times 70$. figs 6-16 Strachanognathus parvus (Rhodes, 1955). Specimens from sample D842. fig. 6, qg element inner specimen GLAHM 109215, $\times 70$; fig. 7, qt element inner, specimen GLAHM 109216, ×70; fig. 8, specimen GLAHM 109217, qt element inner, $\times 70$; fig. 9, ae element, specimen GLAHM 109218, ×70; fig. 10, ae element, specimen GLAHM 109219, ×70; fig. 11, qa element inner, specimen GLAHM 109220, $\times 70$; fig. 12, qa element outer, specimen GLAHM 109221, D842, ×70; fig. 13, pt element outer, specimen GLAHM 109222, ×70; fig. 14, pt element inner, specimen GLAHM 109223, $\times 70$; fig. 15, pf element outer, specimen GLAHM 109224, $\times 70$; fig. 16, pf element inner, specimen GLAHM 109225, $\times 70$. figs 17-20 Eoplacognathus lindstroemi (Hamar, 1966). Specimens from sample D842. fig. 17. Pa element, specimen GLAHM 109226, sample D842, $\times 70$; fig. 18, Pa element, specimen GLAHM 109227, ×70; fig. 19, ?Pc element specimen GLAHM 109228, ×70; fig. 20. ?Pb element, specimen GLAHM 109229, $\times 70$. 


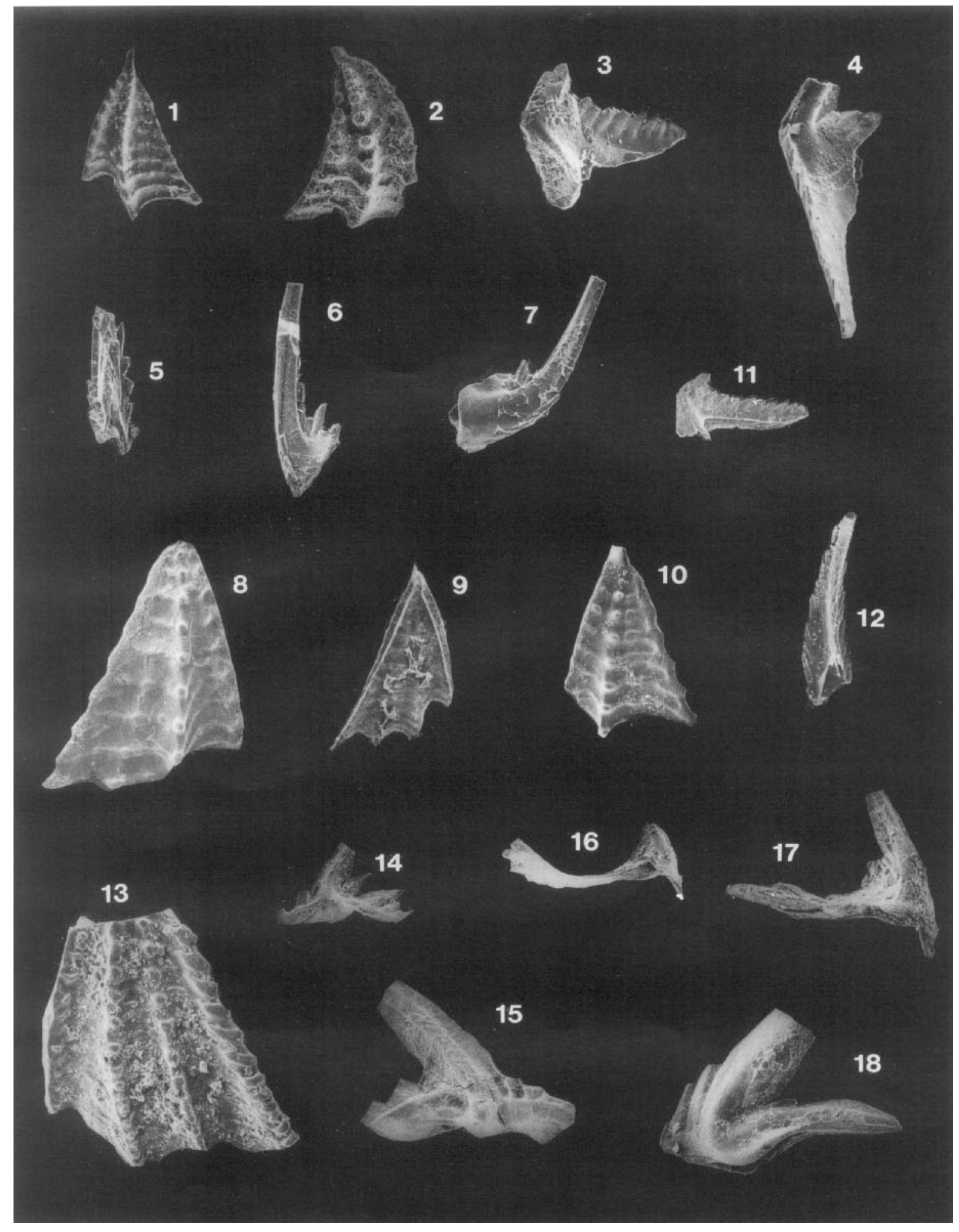

Explanation of Plate 6

figs 1-7 Pygodus serra (Hadding, 1913). Specimens from D842. fig. 1, Pa element, specimen GLAHM 109230, $\times 50$; fig. 2, Pb element, specimen GLAHM 109231, × 50; fig. 3, Pc element lateral view, specimen GLAHM 109232, ×70; fig. 4, ?Pd element oblique lateral view, specimen GLAHM 109233, $\times 70$; fig. 5, M element posterior view, specimen GLAHM 109234, $\times 70$; fig. 6, ?Sc element, specimen GLAHM 109235, $\times 70$; fig. 7, Sc element, specimen GLAHM 109236, ×70. figs 8-13 Pygodus anserinus (Lamont \& Lindström, 1957). Specimens from sample D841. fig. 8, Pa element oral view, specimen GLAHM 109237, $\times 70$; fig. 9, Pa element aboral view, specimen GLAHM 109238, $\times 70 ;$ fig. 10, Pb element oral view, specimen GLAHM 109239, $\times 70$; fig. 11, Pc element lateral view, specimen GLAHM 109240, $\times 70$; fig. 12, M element posterior view, specimen GLAHM 109241, $\times 70$; fig. 13, Pa element oral view, specimen GLAHM 109242, $\times 50$. figs 14-18 Periodon aculeatus (Hadding, 1913). Specimens from D842. fig. 14, Pa element, specimen GLAHM 109243, $\times 50$; fig. 15, Pa element, specimen GLAHM 109244, $\times 50$; fig. 16, Pb element, specimen GLAHM 109245, $\times 50$; fig. 17, Pb element, specimen GLAHM 109246, $\times 50$; fig. 18, M element, specimen GLAHM $109247, \times 50$. 
characters shared with members of the Prioniodinidae (see also generic discussion of Spinodus). However, the denticles on all elements of Periodon are fused almost to their tips. Based on these criteria it would appear logical to retain the family Periodontidae for Periodon and Microzarkodina (Sweet, 1981) but place the family in the order Prioniodinida. The absence of a posterior process in the $\mathrm{Sb}$ elements and the dolabrate $\mathrm{M}$ element suggests a common ancestry with Erismodus Branson \& Mehl, 1933.

Family ?Prioniodinidae Bassler 1925

Genus Spinodus Dzik, 1976

Type species. Polygnathus spinatus Hadding, 1913.

Remarks. Lindström (1964) recognised a symmetry transition series including three elements previously described as $C$. ramosus Hadding and $C$. spinatus (Hadding). Uyeno \& Barnes (1969) added a fourth element to $C$. spinatus. Barnes \& Poplawski (1973) described a quadrimembrate apparatus for C. ramosus. The affinities of Spinodus are, however, problematic.

The gross morphology of the elements suggests two competing phylogenetic hypotheses. One is that Spinodus be assigned to the Chirognathidae with a possible ancestor in Erraticodon, the oldest known chirognathid (Dzik, 1994). Members of this family have an apparatus characterized by a pastinate $\mathrm{Pa}$ element, a digyrate $\mathrm{Pb}$ and modified digyrate $\mathrm{M}$ or, as in Chirognathus, an alate M element (Sweet, 1981). Alternatively, members of the Prioniodinidae, for example Oulodus, have an extensiform digyrate elements in both $\mathbf{P}$ locations or, extensiform digyrate $\mathrm{Pa}$, a breviform digyrate $\mathrm{Pb}$ and a denticulate bipennate or dolabrate M element (Sweet, 1981; Armstrong, 1990).

In his reconstruction of $S$. spinatus, Dzik (1994) designated the digyrate element as the $M$, consistent with a chirognathid affinity. However, this reconstruction left the $\mathbf{P}$ locations to be filled by dolabrate elements, a feature not seen in either chirognathids or prioniodinids. The apparatus reconstruction favoured herein contains a breviform digyrate $\mathrm{Pa}$ (Pl. 7, fig. 11), breviform digyrate $\mathrm{Pb}$ (Pl. 7, fig. 12) and dolabrate $\mathrm{M}$ element (Pl. 7, figs 7, 14); the Pa element is distinguished in possessing a short anticusp. The ramiform elements include an alate Sa (symmetrical with a long posterior process), a modified tertiopedate $\mathrm{Sb}$ (in which the inner lateral process is reduced to a prominent costa) and a bipennate Sc element. This interpretation places Spinodus as the oldest nember of the Prioniodinidae.

Spinodus spinatus (Hadding, 1913)

(Pl. 7, figs 7-14)

* 1913 Polygnathus spinatus Hadding: 32, pl. 1, fig. 8 .

1913 Corylodus ramosus Hadding: 31, pl. 1, fig. 6.

1976 Cordylodus spinatus (Hadding); Dzik: 424, text-fig. 21c. 1981 Spinodus ramosus (Hadding); Nowlan: 15-16, pl. 4, figs 18-19. 1994 Spinodus spinatus (Hadding); Dzik: 113, pl. 24, figs 22-25, text-fig. 32 .

Holotype. Polygnathus spinatus Hadding, 1913, p. 32, pl. 1, fig. 8. Specimen LO 2347 T (mouldic preservation), from the Climacograptus haddingi Biozone (=Climacograptus putillus in Hadding, 1913) of Fảgelsång, near Lund (upper part of section E15).
Diagnosis. Refer to Dzik (1994, p. 113).

Remarks. Refer to those for the genus.

Order Prinoiodontida Dzik, 1976

Remarks. The Prioniodontida (sensu Aldridge \& Smith 1993) contains at least two major clades, one represented by the coniform Oistodontidae and a non-coniform clade in which taxa bear up to four pairs of $\mathrm{P}$ elements. The latter includes the Balognathidae comprising taxa with at least two $P$ elements and fully differentiated S elements (e.g., Rhodesgnathus and Baltoniodus). The Polyplacognathidae bear at least three $\mathrm{P}$ elements and lack S elements (e.g., Eoplacognathus) and the Pygodontidae contains taxa which bear at least three $P$ elements and a reduced number of S elements (e.g., Pygodus). Dzik (1994) included members of each of these families within the Balognathidae.

Family Polyplacognathidae Bergström, $1981 \mathrm{~b}$ Genus Eoplacognathus Hamar, 1966

Type species. Ambalodus lindstroemi Hamar, 1964, p. 258.

Eoplacognathus lindstroemi (Hamar, 1964)

(Pl. 5, figs 17-20)

* 1964 Ambalodus lindstroemi Hamar: 258, pl. 5, figs 1, 4, 7-8, 10-11; text-fig. 5, nos. $1 \mathrm{a}-\mathrm{b}, 3 \mathrm{a}-\mathrm{b}, 4 \mathrm{a}-\mathrm{b}$.

1971 Eoplacognathus lindstroemi (Hamar); Bergström: 139, pl. 2, figs 15-18.

1994 Eoplacognathus lindstroemi (Hamar); Dzik: 98, pl. 21 figs 69 , text-fig. 23.

Holotype. Ambalodus lindstroemi Hamar, 1964, p. 258, pl. 5, figs 8, 11. Specimen PMO 69791, Ampyx Limestone, Ringerike, Norway.

Diagnosis. Refer to Dzik (1994, p. 98).

Remarks. Bergström (1971) and Dzik (1994) reconstructed the apparatus of this species as bimembrate, herein regarded as the $\mathrm{Pa}$ and $\mathrm{Pb}$ elements. An additional Pc element is distinguished in this small collection. The trimembrate apparatus contains a stelliscaphate $\mathrm{Pa}(\mathrm{Pl} .5$, figs 17,18$)$, in which the single outer and bifurcate inner processes are directed anteriorly at an angle of $45^{\circ}$ to the main carina. The $\mathrm{Pb}(\mathrm{Pl} .5$, fig. 20) is pastinate, in which the posterior process is inwardly deflected inwards at an angle of $100^{\circ}$, the short outer lateral process diverges from the main carina at $90^{\circ}$. The Pc element is also pastinate but the posterior process is reduced to a single denticle; the anterior process is approximately twice as long as that of the $\mathrm{Pb}$ element and distally, discrete denticles are developed. Element homologies follow those proposed for Amorhognathus ordovicicus Branson \& Mehl sensu Armstrong et al., (1996). All elements have a ledge-like platform beneath the denticles.

Family Pygodontidae Bergström, 1981a Genus Pygodus Lamont \& Lindström, 1957

Type species. Pygodus anserinus Lamont \& Lindström, 1957, p. 68.

Remarks. Armstrong (1997) reconstructed the apparatus of the type species $P$. anserinus with a modified prioniodontid plan distinguishing a stelliscaphate $\mathrm{Pa}$, pastiniscaphate $\mathrm{Pb}$, bipennate $\mathrm{Pc}$, tertiopedate $\mathrm{M}$ and an Sc element using the apparatus plan of the Silurian genus Astropentagnathus as a template. 


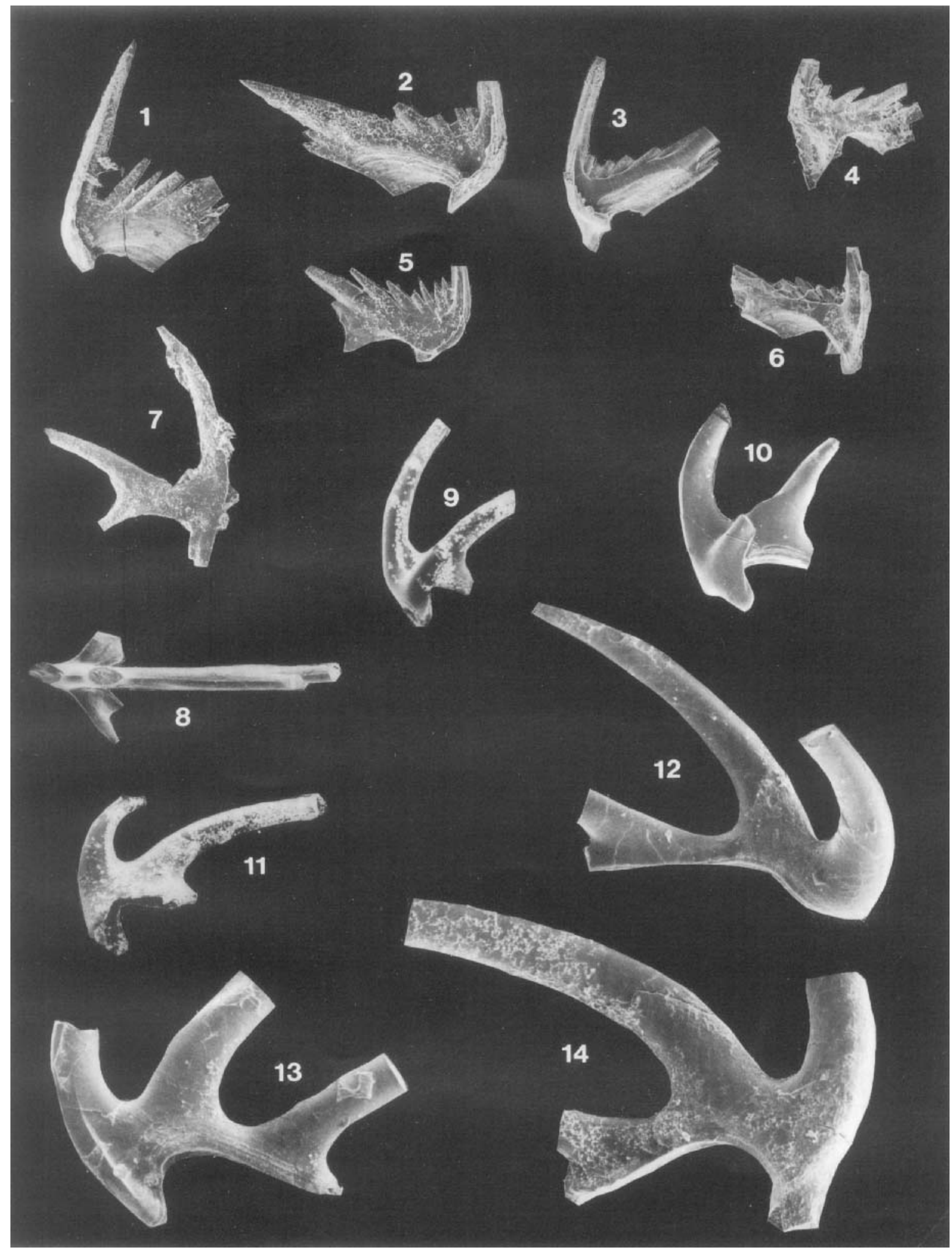

Explanation of Plate 7

figs 1-6 Periodon aculeatus (Hadding, 1913). Specimens from D842. fig. 1, Sa element, specimen GLAHM 109248, $\times 50$; fig. 2, Sa element, specimen GLAHM 109249, ×50; fig. 3, Sc element, specimen GLAHM 109250, ×50; fig. 4, Sb1 element (with lateral process), specimen GLAHM 109251, x50; fig. 5, Sc (lacking lateral process), specimen GLAHM 109252, $\times 50$; fig. 6, Sb2 (bears lateral process), specimen GLAHM 109253, $\times 50$. figs 7-14 Spinodus spinatus (Hadding, 1913). Specimens from D842. Fig. 7, M element, specimen GLAHM 109254, $\times 50$; fig. 8, Sa element oral view, specimen GLAHM 109255, ×50; fig. 9, Sa element lateral view, specimen GLAHM 109256, $\times 50$; fig. 10, Sc element (bears inner lateral process), specimen GLAHM 109257, $\times 50$; fig. 11, Pa element, specimen GLAHM 109258, $\times 50$; fig. 12, Pb element, specimen GLAHM 109259, $\times 70$; fig. 13, Sb element, specimen GLAHM 109260, ×70; fig. 14, M element, specimen GLAHM 109261, ×70. 
Pygodus anserinus Lamont \& Lindström, 1957 (Pl. 6, figs 8-13)

* 1957 Pygodus anserinus Lamont \& Lindström: 68, fig 1a, b. 1957 Pygodus anserinus Lamont \& Lindström: 68, pl. 5, figs 12, 13.

1976 Pygodus anserinus Lamont \& Lindström; Dzik: 440, fig $29 \mathrm{f}$.

1997 Pygodus anserinus Lamont \& Lindström; Armstrong: 777, pl. 4, figs 1-7, text-fig. 4 .

Holotype. Pygodus anserinus Lamont \& Lindström 1957, p. 68, fig 1a, b. Specimen LO $3871 \mathrm{~T}$, from grey trilobite-bearing limestone, Gärdsiösa Bodar, Öland, Sweden.

Diagnosis. Refer to Armstrong (1997, p. 778).

Remarks. $P$. anserinus is distinguished by the $\mathrm{Pa}$ element which bears four rows of nodes. When viewed orally both $\mathrm{Pa}$ and $\mathrm{Pb}$ elements have a much straighter sided, triangular outline than $P$. serra.

Pygodus serra (Hadding, 1913)

(Pl. 5, figs 4, 5; Pl. 6, figs 1-7)

* 1913 Arabellites serra Hadding: 33, pl. 1 figs 12, 13 1971 Pygodus serrus (Hadding); Bergström: 149, pl. 2, figs 2223.

1978 Pygodus serra (Hadding); Löfgren: 98, fig. 32D-F. 1991 Pygodus serra (Hadding); McCracken: 51, pl. 2, figs 1-3, 5, $8,10,13,19$.

Holotype. Arabellites serra Hadding, 1913, p. 33, from upper part of the Lower Dicellograptus Shale, section E15 of Fågelsång near Lund, Skåne, Sweden.

Emended diagnosis. A species of Pygodus in which the $\mathrm{Pa}$ and $\mathrm{Pb}$ elements bear three rows of nodes.

Remarks. Specimens of this species are only found in sample D842. The apparatus reconstruction proposed here follows that for $P$. anserinus (sensu Armstrong, 1997). The $\mathrm{Pb}$ element of $P$. serra has a central row of discrete nodes and in oral view the entire platform is more inwardly bowed than the Pa element. The Pc element exhibits variability in the length of the downturned anterior process.

\section{ACKNOWLEDGEMENTS}

I thank Dr A. W. Owen and Professor E. N. K. Clarkson for long and fruitful discussions on LORS stratigraphy and palaeontology. Professor A. Löfgren kindly read and improved an earlier draft of this paper. The recommendations of Professor R. J. Aldridge and an anonymous referee are greatly appreciated. Dr T. J. Morse processed the samples and printed the photographs. SEM photomicrographs were taken at the University of Edinburgh with the help of Dr M. Lee and in the Department of Geological Sciences, University of Durham. Mrs K. L. Atkinson drew the diagrams. This work was funded by a NERC Small Grant (GR9/02834) held by HAA and Dr A. W. Owen (University of Glasgow).

\section{Manuscript received 27 July 1999 Manuscript accepted 8 March 2000}

\section{REFERENCES}

Aldridge, R. J. \& Smith, M. P. 1993. Conodonta. In Benton, M. J. (Ed.), The Fossil Record 2. Chapman \& Hall, London: 563-572.

Armstrong, H. A. 1990. Conodonts from the Upper Ordovician-Lower Silurian carbonate platform of North Greenland. Bulletin Gronlands Geologiske Undersøgelse, 159, 151pp.

Armstrong, H. A. 1997. Conodonts from the Shinnel Formation, Tweeddale Member (middle Ordovician), Southern Uplands, Scotland. Palaeontology, 40: 763-799.

Armstrong, H. A., Johnson, E. W. \& Scott, R. 1996. Preliminary conodont biostratigraphy of the attenuated Dent Group (Upper Ordovician) at Hartley Ground, Broughton in Furness. Proceedings of the Yorkshire Geological Society, 51: 9-23

Armstrong, H. A. \& Owen, A. W. in press. Age and provenance of limestone clasts in Lower Old Red Sandstone conglomerates: implications for the geological history of the Midland Valley Terrane. In Friend, P. F. \& Williams, B. (eds), New Perspectives of the Old Red Sandstone: tectonics, hydrology and climate. Geological Society, London, Special Publication.

Armstrong, H. A., Owen, A. W. \& Clarkson, E. N. K. 2000. Ordovician limestone clasts in the Lower Old Red Sandstone, Pentland Hills, Southern Midland Valley Terrace. Scottish Journal of Geology, 36, 3338 .

Barnes, C. R. \& Poplawski, M. L. S. 1973. Lower and Middle Ordovician conodonts from the Mystic Formation, Quebéc, Canada. Journal of Paleontology, 47: 760-790.

Bassler, R. S. 1925. Classificiation and stratigraphic use of conodonts. Geological Society of America Bulletin, 36: 218-220.

Bergström, S. M. 1962. Conodonts from the Ludibundus Limestone (Middle Ordovician) of the Tvären area (southeast Sweden). Arkiv foer Mineralogi ö Geologi, 3: 1-64.

Bergström, S. M. 1971. Conodont biostratigraphy of the Middle and Upper Ordovician of Europe and eastern North America. Geological Society of America. Memoir, 127: 83-157.

Bergstrom, S. M. 1973. Biostratigraphy and facies relations in the lower Middle Ordovician of easternmost Tennessee. American Journal of Science, 273-A: 261-293.

Bergström, S. M. 1981. Family Pygodontidae. In Robison, R. A. (Ed.), Treatise on Invertebrate Palaeontology. W (Supplement 2, Conodonta), W132. Geological Society of America, University of Kansas Press.

Bergström, S. M. 1981a. Family Polyplacognathidac. In Robison, R. A. (Ed.), Treatise on Invertebrate Palaeontology. W (Supplement 2, Conodonta), W162. Geological Society of America, University of Kansas Press.

Bergström, S. M. 1986. Biostratigraphic intergration of Ordovician graptolite and conodont zones - a regional review. In Hughes, C. P. \& Rickards, R. B. (Eds), Palaeoecology and Biostratigraphy of Graptolites. Geological Society, London Special Publications, 20: 61-78.

Bergström, S. M. 1990. Biostratigraphic significance of Middle and Upper Ordovician conodonts in the Girvan Succession, south-west Scotland. Courier Forschungsinstitut Senckenberg, 118: 1-43.

Bergström, S. M., Riva, J. \& Kay, M. 1974. Significance of conodonts, graptolites and shelly faunas from the Ordovician of western and north-central Newfoundland. Canadian Journal of Earth Sciences, 11: $1625-1660$.

Bergström, S. M. \& Sweet, W. C. 1966. Conodonts from the Lexington Limestone (Middle Ordovician) of Kentucky and its lateral equivalents in Ohio and Indiana. Bulletins of American Paleontology, 50: $271-441$.

Bluck, B. J. 1978. Sedimentation in a late orogenic basin: the Old Red Sandstone of the Midland Valley of Scotland. In: Bowes, D. R. \& Leake, B. E. (Eds) Crustal Evolution in North western Britain and adjacent Regions. Geological Journal Special Issue, 10: 249-279.

Bluck, B. J. 1983. Role of the Midland Valley of Scotland in the Caledonian Orogeny. Transactions of the Royal Society of Edinburgh: Earth Sciences, 73: 119-136.

Bluck, B. J. 1985. The Scottish paratectonic Caledonides. Scottish Journal of Geology, 21: 437-464.

Bluck, B. J., Gibbons, W. A. \& Ingham, J. K. 1992. Terranes. In: Cope, J. W. C., Ingham, A. J. K. \& Rawson, P. F (Eds) Atlas of Palaeogeography and Lithofacies. Geological Society of London, Memoir, 13: $1-4$ 
Branson, E. B. \& Branson, C. C. 1947. Lower Silurian conodonts from Kentucky. Journat of Pateontology, 21: 549-556.

Branson, E. B. \& Mehl, M. G. 1933. Conodont Studies. University of Missouri Studies, 8.

Clark, D. L. 1981. Classification. In Robison, R. A. (Ed.), Treatise on Invertebrate Paleontology. W (Supplement 2, Conodonta), W102-103. Geological Society of America, University of Kansas Press.

Cooper, B. J. 1975. Multielement conodonts from the Brassfield Limestone (Silurian) of southern Ohio. Journal of Paleontology, 49: 984-1008.

Cooper, B. J. 1976. Multielement conodonts from the St. Clair Limestone (Silurian) of southern Illinois. Journal of Paleontology, 50: 205-217.

Dzik, J. 1976. Remarks on the evolution of Ordovician conodonts. Acta Palaeontologica Polonica, 21: 395-455.

Dzik, J. 1990. Conodont evolution in high latitudes of the Ordovician. Courier der Forschungsinstitut Senckenberg, 117: 1-28.

Dzik, J. 1994. Conodonts of the Mójcka Limestone. In Dzik, J., Olempska, E. and Pisera, A. (Eds) Ordovician Carbonate Platform Ecosystem of the Holy Cross Mountains. Palaeontologia Polonica, 53: $43-128$.

Fåhræus, L. E. 1966. Lower Viruan (Middle Ordovician) conodonts from the Gullhögen quarry, southern central Sweden. Sveriges Geologiska Undersökning, Avhandlingar och uppsatser, Serie C, No. 610, Arsbok, No. 5.

Fortey, R. A., Harper, D. A. T., Ingham, J. K., Owen, A. W. \& Rushton, A. W. A. (1995). A revision of the Ordovician Series and Stages in the historical type area. Geological Magazine, 132: 15-30.

Hadding, A. 1913. Undre dicellograptusskiffen i Skåne jämte några därmed ekvivalenta bildningar. Lunds Universitets Arsskrift, N.F. 2, No. $15 ; 1-90$.

Hamar, G. 1964. The Middle Ordovician of the Oslo Region, Norway, 17. Conodonts from the lower Middle Ordovician of Ringerike. Norsk Geologisk Tidsskrift, 44: 243-292.

Hamar, G. 1966. The Middle Ordovician of the Oslo Region, Norway, 22. Preliminary report on the conodonts from the Oslo-Asker and Ringerike districts. Norsk Geologisk Tidsskrift, 46: 27-83.

Harland, W. B., Armstrong, R. L., Cox, A. V., Craig, L. E., Smith, A. G. \& Smith, D. G. 1990. A Geologic Time Scale 1989. Cambridge University Press, Cambridge, U.K.

Haughton, P. D. W. 1988. A cryptic Caledonian flysch terrane in Scotland. Journal of the Geological Society, London, 145: 685-703.

Haughton, P. D. W. \& Bluck, B. J. 1988. Diverse alluvial sequences from the Lower Old Red Sandstone of the Strathmore region, Scotland Implications for the relationship between the late Caledonian tectonics and sedimentation. In McMillan, N. J., Embry, A. F. \& Glass D. J. (Eds), Devonian of the World. Canadian Society of Petroleum Geologists Memoir, 14: 269-293.

Haughton, P. D. W., Rodgers, G. \& Halliday, A. N. 1990. Provenance of Lower Old Red Sandstone conglomerates, SE Kincardineshire: evidence for the timing of Caledonian terrane accretion in central Scotland. Journal of the Geological Society, London, 147: 105-120.

Lamont, A. \& Lindström, M. 1957. Arenigian and Llandeilian cherts identified in the Southern Uplands of Scotland by means of conodonts, etc. Transactions of the Geological Society of Edinburgh, 17: $60-70$.

Lindström, M. 1955. Conodonts from the lowermost Ordovician strata of south-central Sweden. Geologiska Föreningens $i$ Stockholm, Förhandlingar, 76: 517-603.

Lindström, M. 1964. Conodonts. Elsevier, Amsterdam. 196pp.

Lindström, M. 1970. A suprageneric taxonomy of conodonts. Lethaia, 3: $427-445$.

Lindström, M. 1971. Lower Ordovician conodonts of Europe. Geological Society of America Memoir, 127: 21-61.

Löfgren, A. 1978. Arenigian and Llanvirian conodonts from Jämtland, northern Sweden. Fossils and Strata, 13: 1-129.

Löfgren, A. 1998. Apparatus structure of the Ordovician conodont Decoriconus peselephantis (Lindström 1955). Paläontologiche Zeitschrift, 72: 337-350.
McCracken, A. D. 1989. Protopanderodus (Conodontata) from the Ordovician Road River Group, Northern Yukon Territory, and the evolution of the genus. Geological Survey of Canada, Bulletin, 388, 38pp..

McCracken, A. D. 1991. Middle Ordovician conodonts from the Cordilleran Road River Group, northern Yukon Territory, Canada In Orchard, M. J. \& McCracken, A. D. (Eds) Ordovician to Triassic Conodont Paleontology of the Canadian Cordillera. Geological Survey of Canada, Bulletin, 417: 41-63.

Nowlan, G. S. 1981. Some Ordovician conodont faunules from the Miramichi Anticlinorium, New Brunswick. Geological Survey of Canada. Bulletin, 345, 35pp.

Pander, C. H. 1856. Monographie der fossilen Fische des silurischen Systems der russisch-baltischen Gouvernements. Akademie der Wissenschaften.

Phillips, E. R., Smith, R. A. \& Carroll, S. 1997. Strike-slip, terrane accretion and pre-Carboniferous evolution of the Midland Valley of Scotland. Transactions of the Royal Society Edinburgh: Earth Sciences, 89: 209-224.

Rejebian, V. A., Harris, A. G. \& Huebner, J. S. 1987. Conodont color and texture alteration: An index to regional metamorphism, contact metamorphism and hydrothermal alteration. Geological Society of America, Bulletin, 99: 471-479.

Rhodes, F. H. T. 1955. The conodont fauna of the Keisley Limestone. Quarterly Journal of the Geological Society of London, 111: 117-142.

Sansom, I. J., Armstrong, H. A. \& Smith, M. P. 1994. The apparatus architecture of Panderodus and its implications for coniform conodont classification. Palaeontology, 37: 781-801.

Serpagli, E. 1967. I conodonti dell'Ordoviciano superiore (Ashgilliano) delle Alpi Carniche. Bollettino Societa Paleontologica Italiana, 6: 30111

Smith, R. A. 1995. The Siluro-Devonian evolution of the southern Midland Valley of Scotland. Geological Magazine, 132: 503-515.

Stouge, S. S. 1984. Conodonts of the Middle Ordovician Table Head Formation, western Newfoundland. Fossils and Strata, 16.

Sweet, W. C. 1979. Late Ordovician conodonts and biostratigraphy of the western Midcontinent Province. Brigham Young University Geological Studies, 26: 45-86.

Sweet, W. C. 1981. Morphology and composition of elementsmacromorphology of elements and apparatuses. In Robison, R. A. (Ed.) Treatise on Invertebrate Paleontology. W (Supplement 2, Conodonta), Geological Society of America, University of Kansas Press: W17-20.

Sweet, W. C. 1988. The Conodonta. Morphology, Taxonomy, Paleoecology, and Evolutionary History of a long extinct Animal Phylum. Oxford Monographs on Geology and Geophysics, 10: Oxford University Press, Oxford.

Sweet, W. C. \& Bergström, S. M. 1962. Conodonts from the Pratt Ferry Formation (Middle Ordovician) of Alabama. Journal of Paleontology, 36: $1214-1252$

Sweet, W. C. \& Bergström, S. M. 1966. Ordovician conodonts from Penobscot County, Maine. Journal of Micropalaeontology, 40: 151154.

Sweet, W. C. \& Schönlaub, H. P 1975. Conodonts of the genus Oulodus Branson and Mehl, 1933. Geologica et Palaeontologica, 9: 41-59.

Thirlwall, M. F. 1988. Geochronology of British Late Caledonian magmatism in northern Britain. Journal of the Geological Society, London, 145: 951-967.

Tucker, R. D., Bradley, D. C., VerStraeten, C. A., Harris, A. G., Ebert, J. R. \& McCutcheon, S. R. 1998. New U-Pb Zircon ages and the duration and division of Devonian time. Earth and Planetary Science Letters, 158: 175-186.

Uyeno, T. T. \& Barnes, C. R. 1969. Conodonts from the Levis Formation (Zone D1) (Middle Ordovician), Levis, Quebéc. Geological Survey of Canada, Bulletin, 187: 99-123.

van Wamel, W. A. 1974. Conodont biostratigraphy of the Upper Cambrian and Lower Ordovician of north-western Öland, southeastern Sweden. Utrecht Micropaleontological Bulletins, 10: 1-126. Ziegler, W. (Ed.) 1973. Catalogue of Conodonts 1: Stuttugart. 